\title{
Wastepaper as a Feedstock for Ethanol Production
}

\author{
P. W. Bergeron \\ C. J. Riley
}

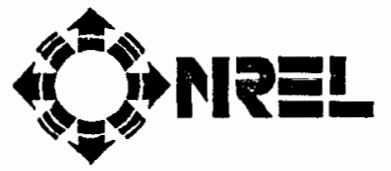

National Renewable Energy Laboratory

(formerly the Solar Energy Research Institute) 1617 Cole Boulevard Golden, Colorado 80401-3393

A Division of Midwest Research Institute Operated for the U.S. Department of Energy under Contract No. DE-AC02-83CH10093

Prepared under task no. DO041010

November 1991 


\section{On September 16, 1991, the Solar Energy Research Iristitute was designated a natlonal laboratory, and Its name was changed to the National Renewable Energy Laboratory.}

\section{NOTICE}

This report was prepared as an account of work sponsored by an agency of the United States government. Neither the United States government nor any agency thereof, nor any of their employees, makes any warranty, express or implied. or assumes any legal liability or responsibility for the accuracy. completeness. or usefulness of any information, apparatus, product, or process disclosed, or represents that its use would not infringe privately owned rights. Reference herein to any specific commercial product, process, or service by trade name. trademark. manufacturer. or otherwise does not necessarily constitute or imply its endorsement. recommendation. or favoring by the United States government or any agency thereof. The views and opinions of authors expressed herein do not necessarily state or reflect those of the United States government or any agency thereof.

Printed in the United States of America

Available from:

National Technical information Service

U.S. Department of Commerce

5285 Port Royal Road

Springfield. VA 22161

Price: Microfiche A01

Printed Copy A03

Codes are used for pricing all publications. The code is determined by the number of pages in the publication. Information pertaining to the pricing codes can be found in the current issue of the following publications which are generally avallable in most libraries: Energy Research Abstracts (ERA); Government Reports Announcements and Index (GRA and I); Scientific and Technical Abstract Reports (STAR); and publication NTIS-PR-360 available from NTIS at the above address. 


\section{Preface}

This report was prepared by Paul Bergeron and Cynthia Riley of the Biotechnology Research Branch of the Fuels and Chemicals Research and Engineering Division. 
TP-4237 


\section{Contents}

Section $\quad \underline{\text { Page }}$

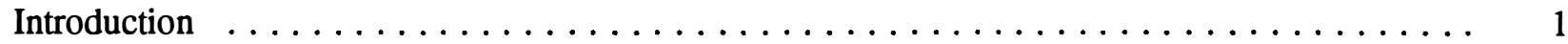

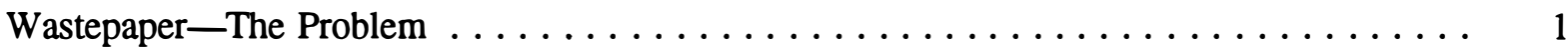

Wastepaper-The Resource $\ldots \ldots \ldots \ldots \ldots \ldots \ldots \ldots \ldots \ldots \ldots \ldots \ldots$

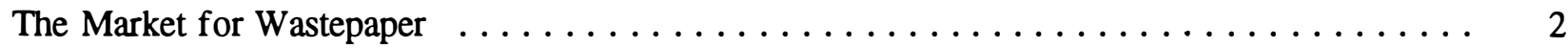

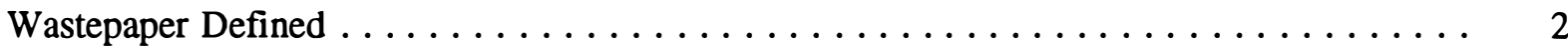

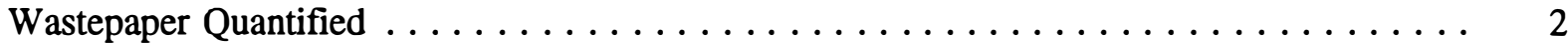

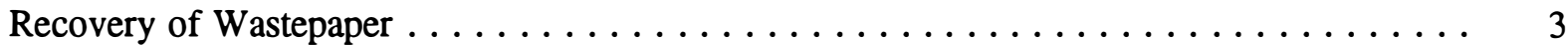

Response of Pulp and Paper Industry to Increasing Wastepaper Supply . . . . . . . . . . . 4

Wastepaper Prices ................................... 4

Other Factors Affecting Wastepaper Demand from the Pulp and Paper Industry . . . . . . 6

Estimates of Potential Ethanol Production from Wastepaper $\ldots \ldots \ldots \ldots \ldots \ldots$

Factors Tending to Reduce Pulp and Paper Industry for Wastepaper $\ldots \ldots \ldots \ldots \ldots$

Wastepaper Grades with Negligible Potential $\ldots \ldots \ldots \ldots \ldots \ldots \ldots \ldots \ldots$

Wastepaper Grades with Limited Potential $\ldots \ldots \ldots \ldots \ldots \ldots \ldots \ldots$

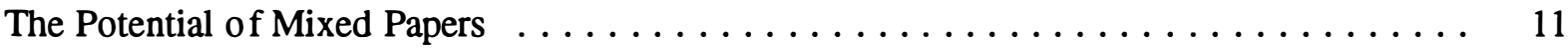

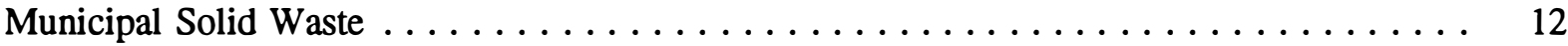

Technical Aspects of Wastepaper Utilization for Ethanol Production $\ldots \ldots \ldots \ldots \ldots$

Nonpaper Components of Wastepaper $\ldots \ldots \ldots \ldots \ldots \ldots \ldots \ldots \ldots \ldots \ldots \ldots \ldots \ldots$

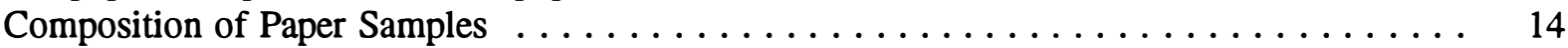

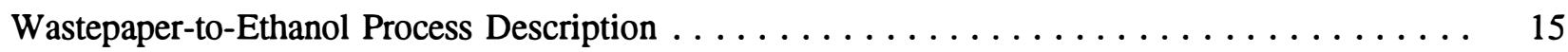

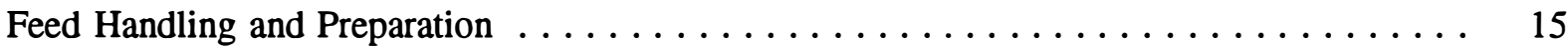

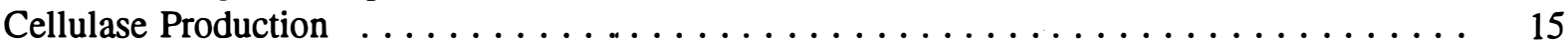

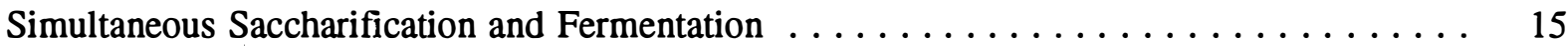

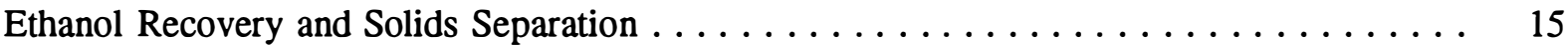

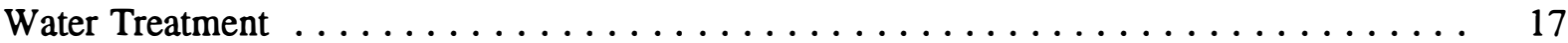

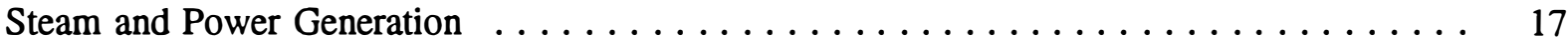

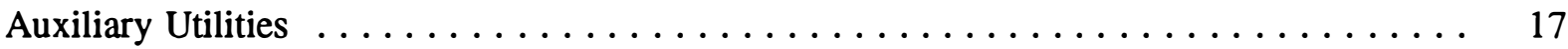

Economic Aspects of Wastepaper Utilization for Ethanol Production $\ldots \ldots \ldots \ldots \ldots$

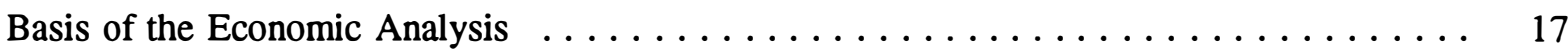

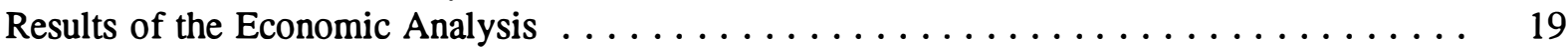

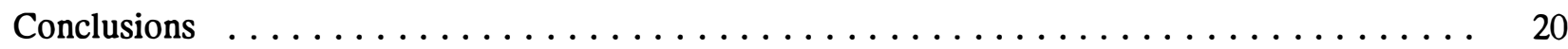

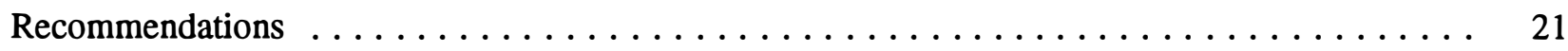

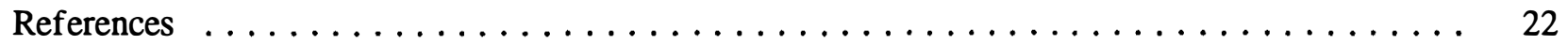




\section{List of Tables}

1. Paper and Paperboard Production (Million Tons) for 1988 and 1995 as Presented in the Franklin Associates/API Report (Franklin 1990) . . . . . . . . . . . . . . . . . .

2. Recovery of Wastepaper by Grade as Reported in the Franklin Associates/API Report (Franklin 1990) ................................ 3

3. Wastepaper Selling Prices $\ldots \ldots \ldots \ldots \ldots \ldots \ldots \ldots \ldots \ldots \ldots \ldots \ldots \ldots \ldots$

4. Break-even ONP Costs (\$/ton) for ONP Pulp versus Virgin Pulp for Different Sizes of

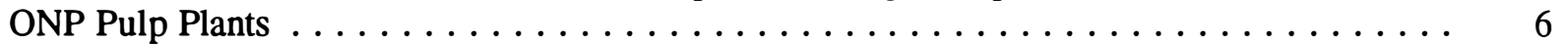

5. Predictions for the Year 2000 of the Total U.S. Tonnage of OCC, ONP, and Mixed Papers . 11

6. Compositions (wt\% on Dry Basis) of Wastepaper Samples Analyzed at NREL . . . . . . 14

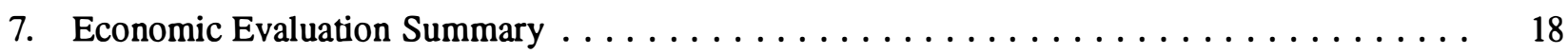

\section{List of Figures}

1. Flow of paper products from production through disposal $\ldots \ldots \ldots \ldots \ldots \ldots$

2. Block flow diagram of the wastepaper-to-ethanol process $\ldots \ldots \ldots \ldots \ldots$

3. Ethanol price as a function of feedstock cost $\ldots \ldots \ldots \ldots \ldots \ldots \ldots \ldots \ldots$ 


\section{Introduction}

\section{Wastepaper-The Problem}

The possibility of using wastepaper as a cheap feedstock for ethanol production arose from the wellpublicized concem about rising landfill costs resulting from shrinking landfill capacity. Shrinking landfill capacity is a result of tighter environmental controls on their siting, construction, and operation, and of the unwillingness of communities to have new landfills sited nearby. Tighter environmental regulations are responsible for the premature closure of existing landfills and higher costs for constructing new ones. According to the National Solid Wastes Management Association (NSWMA), half of the existing 6,034 landfills will be closed by 1995 and, assuming the current rates of landfill closures and openings continue, "disposal requirements will exceed existing capacity by around 1998" (NSWMA 1988). The effect on tipping fee costs is shown by the rise in the national average landfill tipping fee between 1984 and 1988 by a factor of 2.5 to $\$ 26.93 /$ ton, a trend expected to continue. Just examining the national average, however, hides the problem's very regional nature, which is seen in the broad range of local tipping fees ( $\$ 4.75$ to $\$ 120.00 /$ ton) and regional averages (Northeast $\$ 45.48$, South $\$ 15.87$, Midwest $\$ 17.95$, and West \$13.06) (NSWMA 1988).

At 50.1 MM tons discarded in 1986, wastepaper accounted for $35.6 \%$ of the total municipal solid waste (MSW) discarded, and these figures are expected to rise to $66.0 \mathrm{MM}$ tons and $39.1 \%$, respectively, in the year 2000 (Franklin Associates, Ltd. 1988). Because wastepaper is the single largest material category in the MSW stream, it is the main target of efforts to reduce the MSW burden. This is evidenced by the numerous laws being enacted and under consideration by state and local governments aimed at increasing the recovery and recycling of wastepaper.

\section{Wastepaper-The Resource}

This landfill capacity crisis needs to be and is being attacked by a four-pronged waste management approach that includes (1) source reduction to minimize the volume of garbage before it is produced; (2) recycling programs to return recyclable materials to the marketplace; (3) resource recovery to extract energy from the combustible material; and (4) landfilling to dispose of the remainder. The potential use of wastepaper for recycling and energy production points out its value as a resource-as fiber for the paper industry, fuel for direct combustion to steam and/or electricity, and, in the case of ethanol production, carbohydrates for the fermentation process.

For the most part, paper products are made from trees, which are composed of cellulose, hemicellulose, and lignin. Research has been conducted for a number of years on the conversion of such lignocellulosic materials to ethanol. The two polymeric carbohydrates, cellulose (about one-half of the dry weight) and hemicellulose (about one-quarter of the dry weight), can be broken down into their component sugars and fermented to ethanol. The lignin, a phenolic-based polymer comprising about one-quarter of the dry weight, cannot be fermented, but can be used as boiler fuel to supply the energy requirements of the overall conversion process and is a potential source of valuable liquid fuels and chemicals. The chemical composition of paper products differs from the original wood because the various processes used to produce the pulp feed for papermaking are aimed at stripping away the hemicellulose and, in some cases, the lignin, while maintaining the cellulose content.

Research at the National Renewable Energy Laboratory (NREL) and elsewhere has brought down considerably the projected cost (in 1990 dollars) of ethanol from lignocellulosics-from $\$ 3.60 /$ gal ethanol in 1980 to approximately $\$ 1.27 / \mathrm{gal}$ in 1990 . But the single highest cost item in the process is the feedstock, which represents about $38 \%$ of the 1990 cost. When the research goals are reached at the end 
of this decade and ethanol at about $\$ 0.67 / \mathrm{gal}$ (1990 dollars) is realized, the assumed wood feedstock cost of $\$ 34 /$ dry ton will account for almost $50 \%$ of this cost. If wastepaper can be obtained in large enough quantities and at prices well below the assumed wood cost, and if conversion process cost and efficiency are similar to that for wood, a significant reduction in the cost of ethanol will be realized.

\section{The Market for Wastepaper}

The amount of wastepaper that might be available as a feedstock for ethanol depends on the amount that can be collected, the extent of the demand from alternative uses, and the price that can be paid by the alternative uses. Franklin Associates and the American Paper Institute (API), the pulp, paper, and paperboard trade association, examined the issue of wastepaper supply and demand and issued a report summarizing their findings in February 1990 (Franklin 1990). This report presented historical data from 1970 to 1988 and predictions for 1995 about paper and paperboard production and recovery for reuse.

\section{Wastepaper Defined}

To understand these findings, it is necessary to define the categories into which wastepaper is divided. The term wastepaper encompasses a broad range of products from the pulp, paper,and paperboard industry that can be used by that industry as a feedstock substitute for wood. The Department of Commerce has divided wastepaper into five categories as follows: (1) old newspapers (ONP), which are mostly unsold and household newspapers; (2) old corrugated containers (OCC), which include used containers and container plant cuttings; (3) high-grade deinking, which includes computer printouts, sorted white office papers, printing plant scrap, and printed converting scrap; (4) mixed paper, which includes paper of varied quality such as unsorted office papers, magazines, and unsorted household papers; and (5) pulp substitutes, which include various grades of unprinted paper, usually plant scrap. The pulp substitutes category and the plant cuttings and scraps in the other categories are all termed "preconsumer" waste; the remainder is "postconsumer" waste. In general, the sources of preconsumer waste are printers and converters, and sources for postconsumer waste are retailers, offices, industry, and households.

\section{Wastepaper Quantified}

The annual supply of all paper and paperboard products entering the market rose from $56.1 \mathrm{MM}$ tons in 1970 to $86.1 \mathrm{MM}$ tons in 1988 and is predicted to rise to $102.0 \mathrm{MM}$ tons in 1995 (Franklin 1990). After being sold, used, and discarded, most of these paper and paperboard products are soon destined for disposal as wastepaper, recovered and recycled as feedstock for paper products, or burned with MSW for energy recovery. A small fraction ends up in long-term storage in such items as books and various construction products. Table 1 presents a breakdown of paper and paperboard production by product category for 1988 and 1995 . Note that the product categories are different than the wastepaper categories. The product categories represent products that, when disposed of, end up assigned to the wastepaper categories listed above.

Table 1. Paper and Paperboard Production (Million Tons) for 1988 and 1995 as Presented in the Franklin Associates/API Report (Franklin 1990)

\begin{tabular}{rcccccc}
\hline & Newsprint & $\begin{array}{c}\text { Printing/ } \\
\text { Writing }\end{array}$ & $\begin{array}{c}\text { Other } \\
\text { Paper }\end{array}$ & Paperboard & Other & Total \\
\hline 1988 & 13.70 & 24.80 & 10.54 & 35.32 & 1.78 & 86.13 \\
1995 & 15.50 & 32.60 & 11.25 & 40.85 & 1.80 & 102.00 \\
\hline
\end{tabular}


Newspapers, of course, end up in the ONP wastepaper category. The majority of this category is used for recycled newsprint, but significant amounts are also used for tissue products and paperboard boxes. Smaller fractions are used for molded products such as egg cartons and nonpaper products such as cellulose insulation, animal bedding, and mulch products. These nonpaper products represent a small fraction of the present and expected future wastepaper demand. Cellulose insulation has been the major nonpaper product, but its use has declined considerably since 1978, when there were more than 1,000 cellulose insulation manufacturers compared with less than 110 in 1989 (Metropolitan Washington Council of Governments 1989). The market seems to have stabilized, but growth may occur if state laws are passed that are designed to increase government use of highly recycled materials such as cellulose insulation, or if the country again embraces conservation in response to increased energy prices (resulting from policy or supply).

Postconsumer waste from the printing/writing category represents a broad spectrum of products that end up in the high-grade deinking wastepaper category or in the mixed paper category, depending on the grade. High-grade deinking papers and pulp substitutes are used to make tissue and printing/writing papers, and colored paper is recycled into paperboard used to make cereal boxes and related items. The category labeled "other paper" encompasses a variety of products such as packaging and tissue paper. The postconsumer waste from this category for the most part ends up in the mixed paper wastepaper category. If recovered, mixed paper waste can be used to manufacture certain grades of products in the other paper and paperboard categories. Paperboard products are mainly cardboard containers that end up in the OCC category after disposal and, if recycled, are used to make more paperboard products.

\section{Recovery of Wastepaper}

Of the total amount of paper and paperboard produced, the total amount recovered for reuse (domestic and exported) was about $22 \%$ in 1970 and $31 \%$ in 1988 and is expected to be about $39 \%$ in 1995 . Table 2 presents a breakdown of the actual 1988 and the projected 1995 recovery rates for the five wastepaper grades.

Table 2. Recovery of Wastepaper by Grade as Reported in the Franklin Associates/API Report (Franklin 1990)

\begin{tabular}{lcc}
\hline & 1988 & 1995 \\
\hline Wastepaper Category & Percent, MM Tons & Percent, MM Tons \\
\hline Old Newspapers & $34.8,4.8$ & $51.6,8.0$ \\
Corrugated & $51.6,12.4$ & $66.0,18.8$ \\
Mixed Papers & $13.0,2.9$ & $15.0,4.1$ \\
Pulp Substitutes & $100.0,3.6$ & $100.0,4.0$ \\
Deinking & $37.0,2,5$ & $50.0,4.4$ \\
\multicolumn{1}{c}{ TOTAL } & $\mathbf{3 0 . 6 , 2 6 . 2}$ & $\mathbf{3 8 . 5 , 3 9 . 3}$ \\
\hline
\end{tabular}

Do the 1995 recovery rates listed in Table 2 represent the maximum potentially achievable recovery rates? How does this compare to demand for wastepaper from the major users-the domestic and foreign paper and paperboard industries? According to the Franklin Associates/API report, "The principal limitation to ongoing growth in the rate of wastepaper consumption after 1995 will be the fact that the country may be approaching the practical limits of recovery for all grades, except mixed papers" (Franklin 1990). This statement was based on "practical maximum recovery rates" of $63 \%-68 \%$ for corrugated, $50 \%-55 \%$ for newsprint, $50 \%$ for deinking, $100 \%$ for pulp substitutes, and $15 \%-25 \%$ for mixed papers. 
Other organizations have arrived at higher maximum recovery rates; for example, Andover International Associates (AIA) predicts an upper limit of $75 \%$ to $80 \%$ for OCC and $65 \%$ for ONP (Iannazzi 1990). The NSWMA also estimates a $65 \%$ recovery rate for ONP to be achieved in the year 2000 (The Future of Newspaper Recycling 1990). This assumes that, of the 17.2 MM tons of newsprint consumed, 11.2 MM tons of ONP will be recovered. Taking into consideration ONP exports (2.5 MM tons), other domestic papermaking applications (2.5 MM tons), use of old magazines with the ONP to enhance the flotation deinking process, and fiber losses in the deinking process, about $8.4 \mathrm{MM}$ tons of deinked fiber will be used in the year 2000 . This represents about a $40 \%$ recycled fiber content in the $21.3 \mathrm{MM}$ tons predicted to be consumed in North America.

\section{Response of Pulp and Paper Industry to Increasing Wastepaper Supply}

These studies assume that essentially all of the collectible wastepaper, with the exception of mixed papers, will be able to be used in the foreign and domestic paper and paperboard industries. This implies that product quality will not be so adversely affected by higher recycled paper content that consumer demand will drop, and that the pulping industry will have the required wastepaper processing capacity. The product quality issue is one that is still under investigation and open to debate. As fibers are repeatedly repulped, their physical properties change in a way that generally damages their papermaking properties and/or hinders the papermaking process. As the wastepaper recovery rates increase, the recycled portion of the feedstock will contain higher percentages of fibers that have been recycled more than once. The potential impact on each grade is unknown but generally higher quality paper grades, the numerous printing and writing paper grades, will be more susceptible to product quality problems. The impact of these problems may be minimized by marketing approaches that emphasize the environmental benefits of using recycled paper. The grades at the lower end of the quality spectrum-newspaper, tissue papers, and containerboard-already have products on the market with considerable recycled content. How well the public accepts or demands recycled products is a key issue in determining how much the industry will ultimately use.

The issue of having the required wastepaper deinking and pulping capacity in place is linked to the product quality issue and, therefore, depends on the grade of paper being considered. The lower quality grades already have considerable recycling capacity and much more is being planned for the near future. The importance of this issue is demonstrated by the current glut of ONP, which is the result of insufficient deinking capacity. Whereas the supply of wastepaper used to be linked to market demand, in turn dependent on deinking capacity, the recent interest in waste management has spurred the collection of ONP regardless of market demand. The short-term result is much lower ONP prices, but the longer-term result is a remendous expansion in deinking capacity planned over the next five years. Similar expansion of recycling capability is scheduled for the tissue and containerboard markets. In fact, there is concern among some executives in the industry that ONP and OCC will be in short supply and their prices will rise substantially. Based on this response, the predicted ability of the pulp and paper industry to consume the ONP and OCC at future recovery rates cited earlier seems appropriate.

\section{Wastepaper Prices}

Having reviewed wastepaper recovery rates and potential demand from the pulp and paper industry, it is now important to ry to determine the prices that the industry may be willing to pay. As with any commodity market, prices fluctuate over time because of imbalances in supply and demand. As noted previously, supply/demand imbalances for some grades have been aggravated by the recent environmentdriven rather than demand-driven increase in supply. It is, nonetheless, instructive to review recent wastepaper prices to get an idea of what the pulp and paper industry has been able to afford in the past. 
The industry newsletter, Pulp \& Paper Week, lists wastepaper prices for various grades each month for four locations-New York City (NYC), Chicago, Atlanta, and Los Angeles (LA)-San Francisco (SF) (Pulp \& Paper Week 1990). For the months of July through October, 1990, the freight on board (FOB) prices for various sorted postconsumer deinking grades ranged from $\$ 45 /$ ton (unusually low for deinking grades) for colored ledger paper up to $\$ 200 /$ ton for computer printout-prices similar to previous years. Table 3 summarizes prices for ONP, OCC, and mixed papers. The prices represent contract rather than spot prices and do not include transportation from the seller's dock to the pulp mill.

Table 3. Wastepaper Selling Prices

\begin{tabular}{lcccc}
\hline \$/ton, FOB & NYC & Chicago & Atlanta & LA-SF \\
\hline ONP - 1990 & -9 to 1 & $0-14$ & $10-16$ & $28-30$ \\
ONP - 1988 & 47 & 43 & 49 & 63 \\
ONP-A verage & 37 & 37 & 40 & 48 \\
OCC - 1990 & $15-25$ & $23-25$ & $39-44$ & $51-58$ \\
OCC - 1988 & 65 & 44 & 50 & 78 \\
OCC-Average & 36 & 41 & 46 & 55 \\
Mixed - 1990 & 0 & $0-3$ & $5-10$ & $5-10$ \\
\hline
\end{tabular}

Notes:

(1) 1990 prices are averages for months of August through October (Miller Freeman 1990).

(2) The "average" prices and the 1988 prices are from Pulp and Paper 1989 Fact Book (Miles 1989).

(3) The "average" prices were calculated from 1980 through 1987 annual data, not corrected for inflation.

(4) Data for mixed papers were only available for 1990.

Prices for deinking grades and pulp substitutes are not listed here because of the high prices of the former and the already high recovery rate of $100 \%$ for the latter. Reviewing Table 3, four important observations can be made: (1) a dramatic drop in prices of ONP and OCC occurred between 1988 and 1990; (2) there can be considerable regional variation in prices; and (3) although OCC and ONP prices in NYC and Chicago were low in 1990, those prices have historically been higher than what can be considered "cheap" (less than $\$ 34 /$ ton) for ethanol production; and (4) the mixed paper prices were cheap in all regions during 1990 , although no historical data were found for this category.

The major implications from these observations are (1) when supply and demand of ONP and OCC are roughly in balance as was the case between 1980 and 1988, ethanol production cannot compete for their use as a feedstock; (2) as the pulp and paper industry continues to expand its capacity to process wastepaper and demand reaches the collectibility limits of supply (as predicted by Franklin Associates, AIA, and NSWMA), historical OCC and ONP prices will retum; and (3) from the limited data, mixed papers appear to be a potential cheap feedstock nationwide. The NSWMA examined the ONP price issue from a different angle - the price necessary for ONP to outcompete virgin fiber as a newsprint feedstock (The Future of Newspaper Recycling 1990). This takes into account the capital and operating cost differential in processing wood chips versus ONP. The study compared the cost of pulp from a new and an existing TMP (thermomechanical pulping, i.e., virgin pulp) facility with that from ONP pulping 
facilities of three sizes-200, 400, and 600 tons per day (tpd). Table 4 lists for each case the break-even cost of ONP, the cost below which ONP is the economically preferred feedstock.

Table 4. Break-even ONP Costs (\$/ton) for ONP Pulp versus Virgin Pulp for Different Sizes of ONP Pulp Plants

\begin{tabular}{ccc}
\hline Plant Size & Existing Facility & New Facility \\
\hline Deinked ONP-200 tpd & 8 & 45 \\
Deinked ONP-400 tpd & 43 & 82 \\
Deinked ONP-600 tpd & 58 & 95 \\
\hline
\end{tabular}

The data in Table 4 indicate that the only economically promising case is that for all but the smallest existing TMP plants ONP is the preferred feedstock even at high ( $>\$ 42 /$ ton) ONP costs. The allowable ONP cost increases because of economies of scale of the deinking process. This study assumes that the price of wood will remain constant regardless of inroads into the market by ONP. It seems more likely that suppliers of wood would reduce their price rather than reduce their volume of sales. The question is: how much of their volume would be lost compared to present markets? The NSWMA study (1988) predicts a $65 \%$ ONP recovery rate in the year 2000 and translates this to an average $40 \%$ recycled fiber content for North American newsprint. Reducing by $40 \%$ the predicted year 2000 total newsprint demand of 21.3 MM tons results in a virgin fiber demand of $12.8 \mathrm{MM}$ tons compared with $15.6 \mathrm{MM}$ tons consumed in 1988 (Iannazzi 1990). How much this potential loss of virgin fiber sales of $2.8 \mathrm{MM}$ tons or $18 \%$ of 1988 volume might affect the break-even ONP price is uncertain. Although the direction of change should be downward, the extent depends on several factors, including the ability of North American forests to sustain current production levels and the future size of markets for other wood products such as lumber both at home and abroad.

\section{Other Factors Affecting Wastepaper Demand from the Pulp and Paper Industry}

There are other factors that influence the pulp and paper industry's demand for wastepaper. A homogeneous and well-characterized feed stream is important to the cost-effective utilization of the waste material. This is the major reason that the mixed paper prices listed in Table 3 are so low. The presence of contaminants that might affect product quality and/or process operability is another important consideration. Food waste, adhesives found in bindings, and plastics from such items as plastic bags also have adverse effects on the papermaking process and product quality.

Geographic location, reliability of supply, and degree of concentration of the wastepaper also are important factors that influence demand. The effect of geographic location on price is illustrated in Table 3, which shows the considerably higher price demanded for ONP and OCC in the LA-SF area than elsewhere. The key is proximity to a market-be it domestic deinking facilities or foreign buyers-or to cheap transportation to that market (ship, barge, and train rather than truck).

The effect of wastepaper concentration is obvious - the more concentrated the supply, the cheaper the collection system. Therefore, metropolitan areas are the prime targets of wastepaper collection systems and the preferred proximity for future dedicated wastepaper deinking and pulping mills. The issues of reliability and collectibility of supply are being addressed by a variety of types of arrangements among wastepaper brokers, municipalities, and pulp and paper companies. Browning-Ferris Industries (BFI) is one of the largest U.S. waste collectors, operating more than 150 curbside collection programs. BFI has 
recently contracted to supply Weyerhauser with up to 120,000 tons per year (tpy) of wastepaper. To get an idea of how far wastepaper can be collected economically, BFI will be shipping from its locations in Arizona, California, Nevada, Oregon, Washington, and British Columbia to Weyerhauser sites in Washington.

Backhauling arrangements with transport companies also are being made, which will help to keep transportation costs down. Trucking companies have traditionally negotiated cheaper rates for hauling wastepaper to mills from which they have delivered the finished product. In this way, a haul is assured for the return trip rather than no load. Rail lines are beginning to compete for the backhaul market to meet the increasing needs of wastepaper transport.

An example of more direct involvement in wastepaper collection to improve reliability of supply is the Southeast Paper Manufacturing Company, which has the largest U.S. mill making newsprint from 100\% recycled fiber in Dublin, Ga. It has started a subsidiary called Southeast Recycling Corporation in Atlanta, which has established a network of wastepaper procurement and processing centers mainly in Georgia and Florida, but also in Maryland, Virginia, Alabama, and Louisiana. Direct involvement between mills and retail stores (OCC from supermarket chains, for example) has already begun.

The industry is also expected to start dealing directly with local governments in efforts to ensure supply reliability. State and municipal governments have already begun to take a more active role in encouraging community-based recycling programs to maximize and stabilize supply. Keeping in mind the effects on recycling programs of the recent drastic drop in wastepaper prices, these governments will favor direct contracts with mills to ensure an adequate level of demand for their wastepaper.

Finally, the ability and willingness of state and local governments to pass laws mandating recovery of wastepaper is an extremely important factor affecting the availability of wastepaper for ethanol production. The effect can be positive or negative to ethanol production potential depending on the approach taken. The effect would be negative if the intent of legislation is to regulate the demand side of wastepaper by, for example, mandating levels of recycled fiber in finished products from the paper and paperboard industry. The alternative to this is to write legislation or initiate community programs that encourage recycling and, thereby, target the supply side. This latter approach can be augmented with contractual agreements between local governments and those companies from any industry interested in the resource. This supply-side approach would ensure markets for the collected wastepaper while maintaining end-use market flexibility. There is currently great interest in the demand-side approach to legislation. Whether this will continue and predominate is hard to predict at this time.

\section{Estimates of Potential Ethanol Production from Wastepaper}

As stated previously, projections of how much wastepaper will ultimately be available for ethanol production depend on the total amount of wastepaper generated, the fraction of the total that can be economically recovered, and the competition for the recoverable portion-factors that vary among the five categories of wastepaper. Overall, the amount generated depends directly on the amount of paper and paperboard products consumed, and reasonably accurate predictions of this are easily obtained. The economically recoverable fraction and the competition for that fraction are less easily predicted. The paper and paperboard industry, domestic and foreign, is by far the largest consumer of wastepaper and because of its potential appetite the prices it is willing to pay should determine wastepaper prices for much of the wastepaper supply. 
Noting the current spate of legislation mandating increasing recycled fiber content in paper products and citing the current industry plans for large-scale expansion of wastepaper processing capacity as well as an increasing wastepaper demand from abroad, experts predict that wastepaper demand as feedstock for paper and paperboard production will press the limits of the collectible wastepaper supply by the end of the decade. If this is accurate, historical prices for key categories of wastepaper will be realized and, perhaps, exceeded. The result would be that the price of much of the potential wastepaper supply would be out of reach of ethanol production.

\section{Factors Tending to Reduce Pulp and Paper Industry Demand for Wastepaper}

Pulp and paper industry demand for wastepaper would be lessened if some or all of the following occur:

- Wastepaper collection systems are more efficient than predicted.

- Paper product quality using the higher levels of recycled fiber is too adversely affected.

- Increasing recycled fiber content (especially those fibers recycled numerous times) and contaminant content of feed increases processing cost more than anticipated.

- Legislation is not aimed at forcing the recycling of wastepaper to paper products.

- Prices for virgin pulp drop appreciably.

- Domestic and/or foreign paper markets do not grow as anticipated, thereby reducing revenues to fund wastepaper conversion projects.

By the end of the decade, these and the related wastepaper issues should be settled and the magnitude of the paper and paperboard industry's demand potential should be determined. The year 2000 has been chosen as the time frame for estimating the potential production of ethanol from wastepaper because of the resolution of pulp and paper industry's role in recycling and because the biomass-to-ethanol conversion technology currently undergoing research and development (R\&D) is expected to mature at that time. This presents a worst case for ethanol potential because it assumes that no diversion of wastepaper for ethanol production will occur prior to 2000 . The price and physical structure of wastepaper may prove superior to the standard biomass feedstocks investigated so far. This could result in a shorter time frame for developing an economical conversion process than that anticipated for other feedstocks. Also, during the decade, the pressure will be on the industry to recycle the wastepaper. However, it is important to note that increased wastepaper use will be very costly to the pulp and paper industry. This fact, combined with varying degrees of uncertainty related to various aspects of wastepaper use-the reliability and cost of the wastepaper resource, and the impact on the paper process and the product quality-make many in the industry nervous about the anticipated expansion in wastepaper usage. Therefore, there may be support for, or at least not opposition to, the consumption of wastepaper supplies by alternative technologies such as ethanol production if that technology is ready to utilize the wastepaper before the pulp and paper companies invest in its use. The sooner a technology is ready to utilize the wastepaper resource and thereby reduce the wastepaper disposal problem, the more of that resource it may be able to command. Conversely, once a pulp and/or paper company invests in wastepaper processing, it will not be denied the feedstock, and as previously shown it can easily outbid other major users, ethanol production in particular.

As noted in the previous section, the paper and paperboard industry is not as interested in mixtures of papers and in contaminated paper. This, along with geographic and demographic factors, should result in opportunities for diverting some of the wastepaper stream to ethanol production. Figure 1 depicts the flow of paper from the mill through the consumer and into the wastepaper stream. The side streams from 


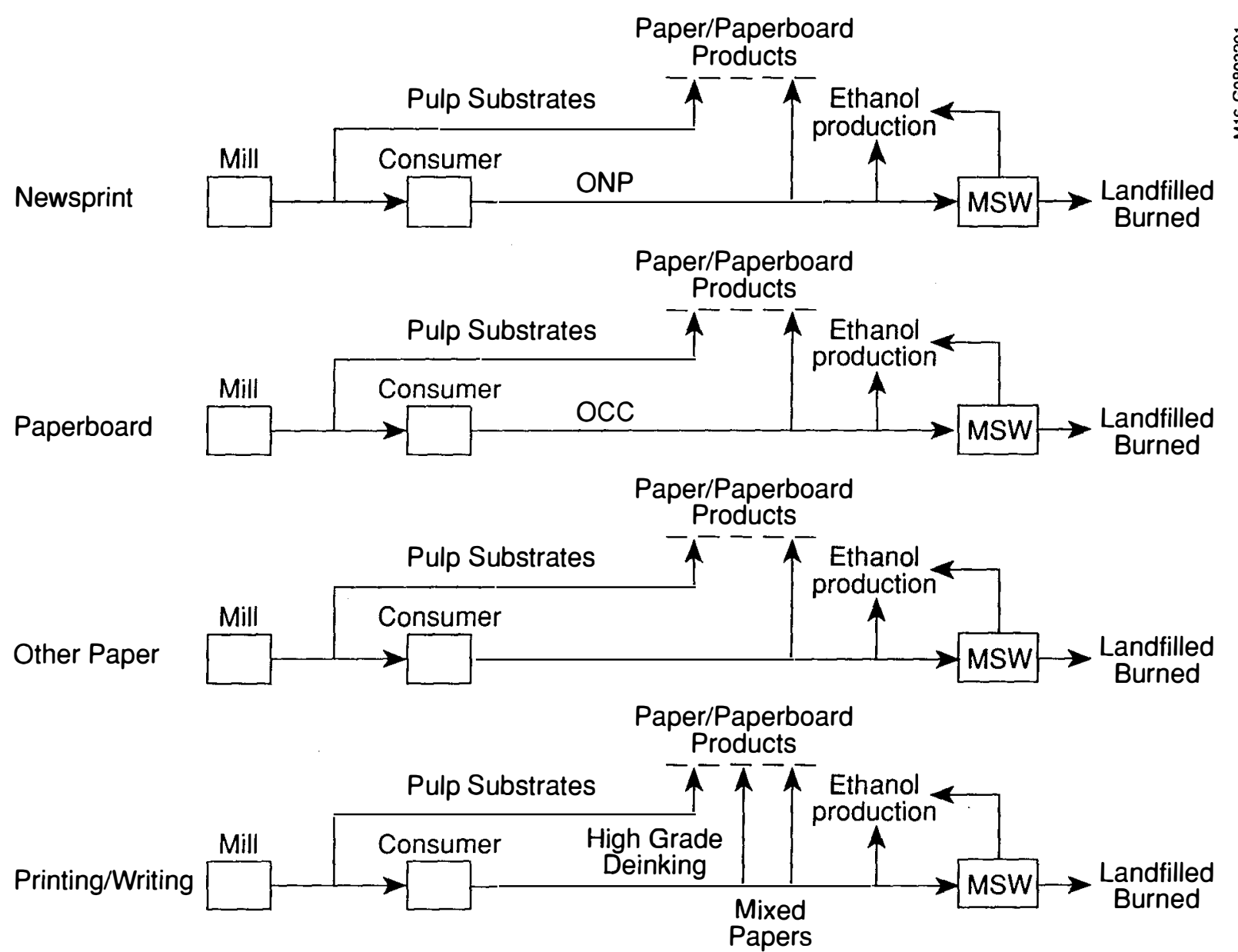

Figure 1. Flow of paper products from production through disposal 
the wastepaper stream represent the recovery of a portion of that paper product, now categorized in one of the wastepaper categories, for various uses. As pictured, the paper and paperboard industry, because of the size of its demand and the prices it can pay, gets first crack at the wastepaper, followed by other potential major users. That portion of the wastepaper stream recovered prior to its being mixed with other wastes in MSW is the result of a public and/or private collection system. Once mixed in with other wastes in MSW, there is the possibility of recovering a portion of the wastepaper for uses where contamination is acceptable.

\section{Wastepaper Grades with Negligible Potential}

The pulp substitutes and high-grade deinking paper grades of wastepaper have negligible potential for ethanol production because of the already $100 \%$ recovery of pulp substitutes and the historically high price of high-grade deinking papers. The deinking grades represent a fraction of the potentially mixed paper waste that is sorted out and recycled because of its high value.

\section{Wastepaper Grades with Limited Potential}

Both OCC and ONP have limited potential for ethanol production because of intensive recovery and recycling within the domestic and foreign paper and paperboard industries. In the case of OCC, recovery rates are already at 52\% and are predicted to rise to a low estimate of 63\% (Franklin 1990) and to a high of $80 \%$ (Iannazzi 1990). The existing OCC recovery rate and much of its predicted increase comes from industrial and large commercial sources where substantial volumes are easily collected and packaged for shipping. Because of limited product quality concerns, considerable existing and expanding OCC processing capacity, and an established collection system, achieving at least the low estimate of $63 \%$ recovery rate seems virtually assured.

Table 5 presents predictions of OCC production and unrecovered amounts for the year 2000 when the pulp and paper industry is expected to attain its maximum wastepaper recovery rates. The table also shows the portion of each not collected for paper products (1000 tons), the percentage of the uncollected amounts recoverable for ethanol production, and the resulting potential ethanol production from this recoverable portion (MM gallons). The production figures for 2000 were not predicted past 1995 and so were extrapolated from those for 1995 using the same average yearly increase as presented for the period of 1988 to 1995 (Franklin 1990). The unrecovered amounts were calculated for 2000 using the upper and lower limits to the predicted ultimate collectibility cited above-63\% to $80 \%$. It was then assumed that the uncollected OCC would be distributed among households and small commercial establishments similar to the distribution of ONP. This was based on the further assumption that the paperboard industry would collect its OCC from industrial and large commercial establishments as it is now doing, but would not be interested in the potentially mixed and contaminated sources collected from households and smaller commercial establishments. An example of a previously unforeseen trend that will increase contaminated sources results from the switch from plastic to cardboard containers by fast-food restaurants. This may provide a reliable, easily collected source of food-contaminated waste of no interest to the pulp and paper industry.

Because of the expected similarity in distribution to that for ONP, a 50\%-65\% recovery rate range was then used on this uncollected portion along with a conversion rate of $90 \mathrm{gal}$ ethanol/ton OCC to calculate the total potential ethanol production from OCC. This resulted in an ethanol production range for the year 2000 of about 300-720 MM gal of ethanol. The OCC would probably not be the sole feedstock for an ethanol plant, but would be collected along with other wastepaper.

Table 5 also lists the production, discards, and ethanol potential figures for ONP. These figures were derived in similar fashion to the OCC figures. For ONP, $65 \%$ of production was assumed to be recovery 
Table 5. Predictions for the Year 2000 of the Total U.S. Tonnage of OCC, ONP, and Mixed Papers

\begin{tabular}{lcccc}
\hline & $\begin{array}{c}\text { Total Tonnage } \\
\text { (1000 tons) }\end{array}$ & $\begin{array}{c}\text { Uncollected for } \\
\text { Paper Products } \\
\text { (1000 tons) }\end{array}$ & $\begin{array}{c}\text { \% Recoverable } \\
\text { for Ethanol }\end{array}$ & Ethanol (MM gal) \\
\hline OCC & 29,810 & $5,960-11,030$ & $50-65$ & $270-650$ \\
ONP & 16,950 & $5,930-8,480$ & $0-50$ & $0-340$ \\
Mixed Papers & 36,190 & 27,690 & $50-65$ & $1,090-1,410$ \\
$\quad$ Totals & 82,950 & $39,580-47,200$ & & $1,360-2,400$ \\
\hline
\end{tabular}

for paper production and a range of $0 \%-50 \%$ of the uncollected portion was then assumed collectible for ethanol production. There may be negligible amounts of the uncollected portion available for ethanol production because the targets of the paper industry's collection efforts are the same as for ethanol production-households and small commercial establishments. On the other hand, because we are not discounting as unusable "contaminated" and mixed paper waste, moderate amounts of this may be collectible. Also, there may be localized regions of the country that are too removed from traditional ONP markets, such as domestic deinking facilities and major shipping ports, to be incorporated into the paper industry's collection system. As with OCC, this points to the use of ONP as a cofeedstock with mixed papers and OCC for a particular ethanol plant. The ethanol potential was calculated using a conversion factor of $80 \mathrm{gal}$ ethanol/ton. This is less than the $90 \mathrm{gal} /$ ton figure used for OCC because of the lower cellulose content of ONP relative to OCC.

\section{The Potential of Mixed Papers}

As shown in Table 5, mixed papers represent the largest single potential feedstock for ethanol production, accounting for 1.09-1.41 billion of the total yearly potential of 1.36-2.40 billion gallons of ethanol. The year 2000 production figure was based on the 1995 printing and writing paper figure projected to 2000 in the same way as the OCC and ONP. The upper end of the Franklin Associates, Ltd./API predicted maximum recovery range, $25 \%$, was used to calculate the portion of the wastepaper uncollected for recycling into paper and paperboard products. Once again, a collection rate of $50 \%-65 \%$ was used to estimate the amount of the mixed papers not collected for other uses that would be recoverable for ethanol production because it was assumed that the distribution would be similar to the ONP distribution. A conversion rate of $80 \mathrm{gal}$ ethanol/ton mixed papers was used to calculate the ethanol potential of this wastepaper.

The basic premise here is that it is the mixed and potentially contaminated nature of this grade, not its distribution, that makes it unattractive to the paper industry and therefore available for ethanol production. The greatest potential for mixed papers lies in the areas of highest population density. The less densely populated areas also have potential because the mixed papers can be augmented by OCC and ONP and, perhaps, the more traditional ethanol feedstocks such as woody and herbaceous crops and agricultural residues.

\section{Municipal Solid Waste}

Up to this point, we have focused on papers recovered from the waste stream before they have been mixed with other wastes in MSW. There also exists the possibility of recovering wastepaper and other potential ethanol production feedstocks from MSW. Introduction of the wastepaper into the MSW presents the 
problem of potential contamination with materials such as solvents or pesticides that might hinder the enzymes and microbes used in the ethanol process. The extent of this potential problem is currently unknown. It may be insignificant because of the relatively small amounts likely to be present in the MSW, which will be considerably diluted during the conversion process. If contamination is not a major problem, a closer look will have to be taken at the relative cost of presorting wastepaper or removing it after it is mixed with MSW.

Commercial technology exists to produce a boiler fuel called densified refuse-derived fuel (dRDF or just RDF) from MSW, usually for cofiring with coal. Those components of MSW that either can be economically recycled or that affect combustion too adversely are separated. The degree of separation varies according to the efficiency of the process employed and the local market for the separable components. Generally, aluminum and ferrous metals, certain plastics, and glass are removed and sold for recycling. Also, food and yard waste can be removed for composting. Most of the rest of the material is paper and paperboard waste.

The largely paper and paperboard waste is either fed to boilers as fluff RDF or pelletized prior to burning or transporting. The selling price of the RDF is dependent on local factors, especially landfill tipping fees and energy costs. The RDF facility usually charges the MSW supplier the same tipping fee as charged in the region and in turn has to pay that tipping fee to dispose of whatever has not been sold or used. If the RDF is sold to a utility, a selling price of around $20 \%$ less than the primary fuel can be obtained. If electricity is generated at the RDF facility, the local electricity rate determines the energy-related sales revenue. Plant revenue that comes from the three revenue streams-the tipping fee, the recyclables, and the RDF-must be enough to pay the capital and operating costs of the facility and produce a profit. Generally, revenues from energy sales exceed those from recyclables because of the very large difference in relative volumes. It is unknown at this time if ethanol production would yield more net revenue from the RDF stream than combustion. This depends on local energy costs and the capital and operating costs associated with an RDF/ethanol facility versus those for an RDF/combustion facility, and these data have not yet been collected and analyzed.

An alternative method currently used to extract energy from MSW is the mass burn facility, in which minimal or no separation is performed prior to burning the MSW. There are some environmental concerns about the emissions from mass burn facilities that make siting such facilities difficult. Nevertheless, the number of these facilities is expected to grow and does represent a competitive use for MSW. However, the total amount of MSW after material recovery for the year 2000 is predicted to be $163 \mathrm{MM}$ tons, of which about $83 \%$ or $140 \mathrm{MM}$ tons is expected to be organic rather than inorganic in nature (Franklin 1990). This represents about three times as much potential feedstock as the best case, which is $47 \mathrm{MM}$ tons of pre-MSW wastepaper, listed in Table 5. Because of this and the fact that the competition for its use is from the production of a low-value fuel product rather than a relatively high-value paper product, MSW utilization has substantial potential for ethanol production.

\section{Technical Aspects of Wastepaper Utilization for Ethanol Production}

We will now focus on the effect that the physical and chemical properties of wastepaper will have on the process design and cost of a more traditional wood-to-ethanol plant. The chemical composition will determine how much polysaccharide or sugar potential is present and, therefore, how much ethanol can be produced per ton of paper. The amount of lignin present determines how much energy can be produced from the feedstock to supply the steam and electricity requirements of the process. The physical properties of the wastepaper and the amount of extraneous mineral matter mixed in with the wastepaper 
will have an impact on the front-end processing or the milling and pretreatment steps that prepare the material for the saccharification and fermentation step.

\section{Nonpaper Components of Wastepaper}

That fraction of the wastepaper that is not paper, such as the ink, fillers, coatings, adhesives, and contaminants that may be present, may also have a significant impact on process operation and cost. Printing inks are mixtures of three basic ingredients: a vehicle to carry and help bond the pigment to the paper, the pigment, and various additives. Petrochemical derivatives make up $80 \%$ of these materials. Forest product derivatives comprise another 15\% (Printing Ink Handbook 1988). According to information from the American Newspaper Publishers Association (ANPA) (Cunningham 1990), printing ink accounts for $1 \%-2 \%$ of the weight of newspapers and is composed of 55\%-85\% petroleum or vegetable oil, $6 \%-20 \%$ pigment, and $0 \%-20 \%$ resin. The vegetable oil, e.g. soybean oil, now accounts for only $2 \%$ of the market, but is gaining. The resin component is almost exclusively man-made isoprene hydrocarbon condensation material.

The presence of heavy metals in printing ink pigments has been a concern to those interested in using wastepaper as animal bedding, boiler fuel, and others. Although once used in some colored inks, the presence of heavy metals in ink has been outlawed. Colored inks without heavy metals, such as the organic color pigments, have been introduced to take their place (Printing Ink Handbook 1988). Black ink represents as much as $90 \%$ of printing ink sold and contains carbon black for its color. White pigments, important for their opacity, most commonly contain titanium dioxide. Although the effect of the mostly petroleum-based ink components on the performance of the enzymes and organisms used in the ethanol conversion process has not yet been studied, preliminary saccharification and fermentation tests conducted at NREL with ONP have shown no evidence of inhibitory effects.

Coatings and fillers are used to provide the appropriate surface qualities for ink and to give the paper product the desired look. Newspaper is the lowest quality grade of paper and has the least content of coating and filler. The amount of coating and filler varies considerably among the numerous grades of printing and writing paper, but can account for up to $30 \%$ of the weight of the paper (Miles 1988). Generally, the percent tends to increase as the quality and, therefore, the cost of the finished product increases. Coatings and fillers are composed mostly of benign materials such as clay, calcium carbonate, and titanium dioxide. Although not studied to date, the main effect on the process of these and other (e.g., plastics) biologically inert materials is expected to be the complication of carrying the resultant solids levels through the process.

The plastics, of course, can be burned for process energy along with the other combustible but biologically inert materials such as lignin. Food waste may actually be a source of nutrients for the microbes in the process. It may also present a storage problem related to smells and pests such as rats.

\section{Composition of Paper Samples}

The results of the chemical analysis of samples of ONP, OCC, old magazines, and mixed papers are presented in Table 6. The data from these analyses are presented in terms of the six-carbon sugar glucose, the five-carbon sugar xylose, other sugars, lignin, and ash. The sugars are actually anhydrosugars tied up in the cellulose and hemicellulose polymer matrix. The old magazine sample was a copy of Time magazine, which is an example of a heavily coated paper. The mixed paper sample was obtained from an RDF facility that removed glass, metals, some plastics, and food and yard waste, leaving almost exclusively a mixture of wastepaper. Therefore, this sample is representative of two mixed paper scenarios-extracted from the wastepaper stream before their introduction into MSW and after their introduction into and extraction from MSW as RDF. 
Table 6. Compositions (weight percent [wt \%] on Dry Basis) of Wastepaper Samples Analyzed at NREL

\begin{tabular}{lrrcc}
\hline & ONP & OCC & Old Magazines & Mixed Papers \\
\hline Glucose & 51.7 & 62.3 & 46.8 & 53.0 \\
Xylose & 5.3 & 10.5 & 7.0 & 8.0 \\
Other & 8.1 & 2.4 & 3.0 & 2.6 \\
Sugars & & & & \\
Lignin & 25.3 & 17.9 & 19.0 & 24.7 \\
Ash & 1.1 & 1.6 & 24.1 & 9.6 \\
\multicolumn{1}{c}{ TOTAL } & $\mathbf{9 1 . 5}$ & $\mathbf{9 4 . 7}$ & $\mathbf{9 9 . 9}$ & $\mathbf{9 7 . 9}$ \\
\hline
\end{tabular}

Because of the nature of the analysis, any materials that burn but are not hydrolyzed by concentrated sulfuric acid end up in the lignin category. Plastics and ink are examples. Those materials that neither burn nor are hydrolyzed by concentrated sulfuric acid end up in the ash category. Examples are the inerts such as clay in the fillers and coatings. Although the materials in the lignin category cannot be converted to ethanol, they can be burned to produce steam and electricity to run the process, and any excess electricity can be sold. The materials in the ash category have no value and, in fact, are a liability because they must be moved through the process and disposed.

The glucose is easily and efficiently converted into ethanol, while the xylose is more difficult to convert. The higher percentage of xylose in wood, approximately 25\%, makes it worthwhile to include xylose fermentation in the process. But because of the much lower amounts in wastepaper, it does not appear economical to include this step in the wastepaper process. Some of the xylose is consumed in the production of enzymes, but most of it and the other nonglucose sugars are anaerobically digested to methane, which is burned for process energy. The factors for converting each of the wastepaper categories used for the Table 5 data were based on the conversion of $90 \%$ of the glucose content into ethanol product-approximately corresponding to the ethanol program conversion efficiency goal.

\section{Wastepaper-to-Ethanol Process Description}

The following description is of a generic wastepaper-to-ethanol process based on the simultaneous saccharification and fermentation (SSF) technology. A block flow diagram of the process is shown in Figure 2. The process described here is simpler than the typical biomass-to-ethanol process because the dilute acid pretreatment and xylose fermentation steps in the wood-to-ethanol process are not included for the wastepaper feedstock process.

\section{Feed Handling and Preparation}

The front end of a wastepaper-to-ethanol plant would be very similar to a paper recycling plant. The wastepaper is mixed with water in a beater or hydropulper to separate the fibers via mechanical action and form a fiber/water slurry. The mechanical action is similar to that observed in an ordinary kitchen blender. The slurry is passed through screens and centrifugal cleaners to remove nonfibrous contaminants such as glass, metal, plastic, and other unwanted materials. 


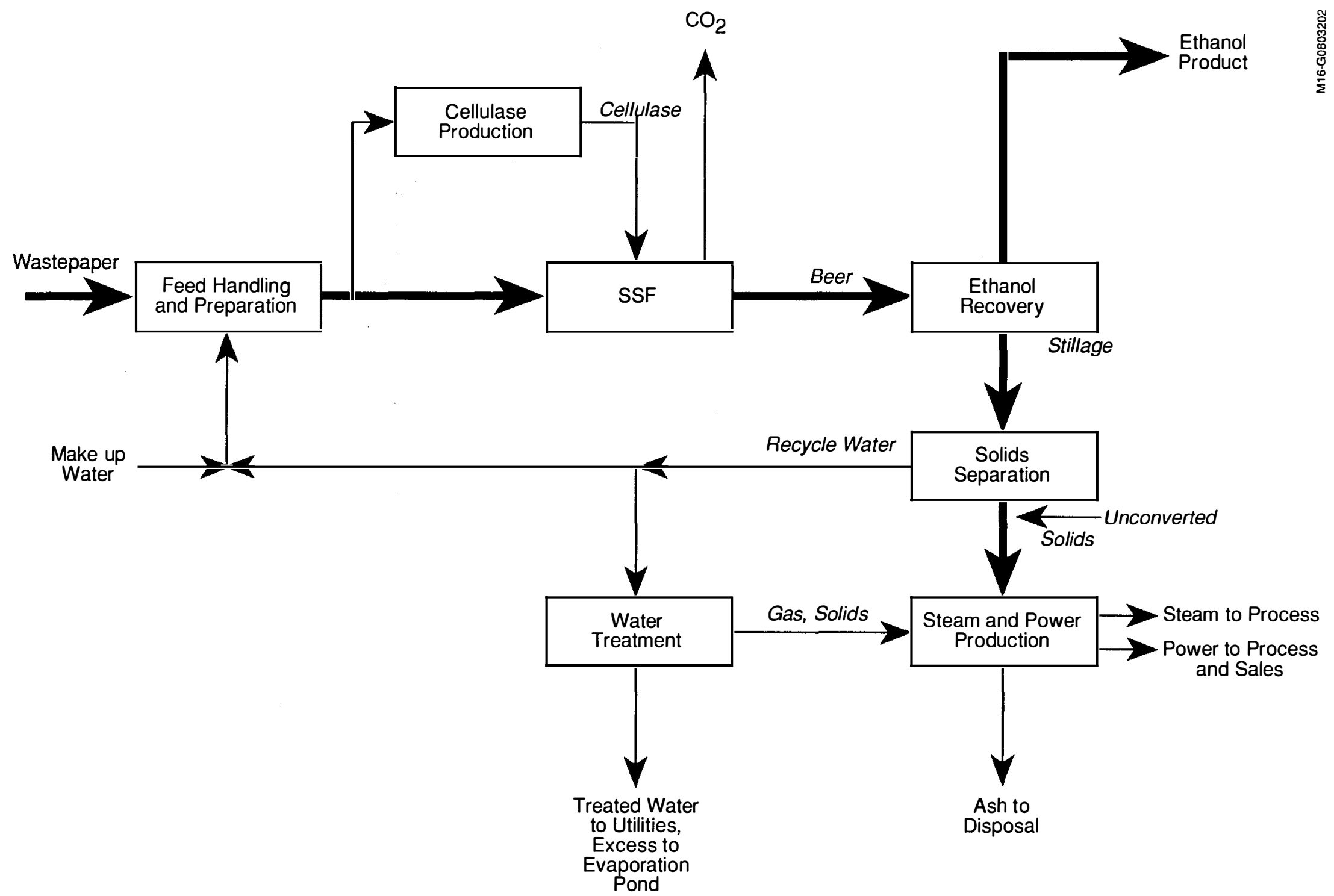

Figure 2. Block flow diagram of the wastepaper-to-ethanol process 


\section{Cellulase Production}

A portion of the prepared slurry is sent to an aerobic fermenter where the cellulose and xylose in the feed are consumed by a fungal microorganism, which produces cellulase enzymes. At the end of the fermentation, the broth containing the enzyme is pumped to the first SSF fermenter. The enzyme is required in SSF to break down the cellulose polymer into glucose molecules (enzymatic hydrolysis). Addition of nutrients and base are required for the cellulase production process. Alternatively, cellulase may be purchased from enzyme manufacturers.

\section{Simultaneous Saccharification and Fermentation}

Broth from cellulase production is combined with the remaining slurry from feed preparation and sent to SSF. In SSF, enzymatic hydrolysis and yeast fermentation steps are combined in one system of vessels. Three potential benefits arise from the combination of steps: end product inhibition of the enzyme is reduced, only one system of vessels and associated equipment is needed, and the presence of ethanol in the hydrolysis/fermentation broth reduces the probability of microbial contamination. Yeast inoculum for SSF is grown in a series of aerobic seed fermenters using a portion of the enzyme broth/slurry mixture. In yeast fermentation, glucose produced by enzymatic hydrolysis is converted into ethanol and $\mathrm{CO}_{2}$. Other products include fuel oils, glycerol, acetaldehyde, organic acids, and cell mass. Offgas from the fermenters flows through a condenser to recover water and ethanol vapor. The remaining offgas, mainly $\mathrm{CO}_{2}$, is vented. At the end of SSF the remaining slurry, or beer, is sent to the ethanol recovery area.

\section{Ethanol Recovery and Solids Separation}

Dilute beer from the SSF system is distilled to produce an ethanol product at a concentration of $95 \mathrm{wt} \%$. Stillage from the bottom of the distillation column is sent to a centrifuge where solids are separated from the liquid portion of the stillage. Solids are composed mostly of unconverted cellulose, insoluble xylans, lignin, and ash. This material is sent to the boiler as fuel. The liquid portion contains unconverted sugars, soluble reaction by-products, and nutrients. A portion of the liquid is recycled to the front end of the plant and used to slurry the incoming wastepaper. Fresh make-up water is used to limit buildup of unwanted by-products in the recycle stream. Liquid that is not recycled is sent to water treatment.

\section{Water Treatment}

The wastewater treatment system consists of three sections: anaerobic digestion, aerobic digestion, and a low-pressure vent system. In anaerobic digestion, approximately $90 \%$ of the organic material, except lignin, is converted to methane, $\mathrm{CO}_{2}$, and cell mass. The gas produced is sent to the boiler as fuel. Wastewater from anaerobic digestion is sent to aerobic digestion where the remaining organics, except lignin, are degraded. Finally the wastewater is filtered, clarified, and recycled to the process for utility purposes. Solids removed during filtration and clarification are sent to the boiler as fuel.

\section{Steam and Power Generation}

The boiler is designed to burn gaseous, liquid, and solid fuels and to generate high-pressure superheated steam. The boiler is sized to handle all the waste streams from the plant. Ash left over after combustion is continuously removed and sent to a landfill. The high-pressure steam is let down through a steam turbine connected to a generator that produces electrical power. Steam is let down to the pressure levels required by the process, and any remaining steam is let down to condensing conditions. 


\section{Auxiliary Utilities}

Numerous other utility systems are provided to support the processing plant. These include boiler feed water treating, process water, cooling water, plant and instrument air, fermentation air, chilled water, and sterilization systems.

\section{Economic Aspects of Wastepaper Utilization for Ethanol Production}

\section{Basis of the Economic Analysis}

Conceptual process designs and economic evaluations were prepared for five cases to determine if there is potential for using wastepaper to produce ethanol. The five cases are as follows:
1. Old newspaper:
current estimate of performance
2. Old newspaper:
future estimate of performance
3. Mixed paper:
current estimate of performance
4. Mixed paper:
future estimate of performance
5. Mixed paper:
future estimate of performance, small plant size.

Mixed paper was chosen as a fcedstock because of its superior potential availability compared with other classes of wastepaper, and ONP because of its near-term potential availability. The plant size for cases 1 through 4 was 2,000 dry tpd of feedstock. This was based on the analyses done using wood as a feedstock. In that situation, 2,000 dry tpd is considered about the minimum economically viable plant size. For case 5, 1,000 dry tpd was chosen to investigate the impact of economies of scale on ethanol selling price. Although reducing plant size increases the ethanol selling price by $\$ 0.13 / \mathrm{gal}$, it decreases either the size of the population or the collection efficiency required to support the plant. Relaxing these requirements increases the number of potential sites that can support an ethanol production facility.

The difference between current and future estimates of process performance was characterized by four parameters: cellulase loading to SSF, cellulose conversion level in SSF, fermentation time in SSF, and SSF seed culture requirements. "Current" performance is based on what has been achieved in the laboratory for the wood-to-ethanol process, and "future" performance represents program goals for the wood-based process. If a plant is built based on current technology, it can still take advantage of process improvements resulting from the research and development that underlies the future technology. The reduction in cost will come in the net cost of production, while the annual capital charge will increase very slightly because of the increased capacity needed in the ethanol recovery and product tankage. The reduced selling price resulting from these process improvements is noted in parentheses in Table 7.

Capital costs for the five cases were capacity-factored estimates based on a detailed cost estimate for the wood-to-ethanol process completed previously (Schell et al. 1991). Modifications to the capital costs were made in areas where the processes were significantly different. Fixed capital costs were based on purchased equipment costs multiplied by an installation factor of 2.85 to cover installation, construction labor, site development, buildings, roads, a control room, laboratories, indirect costs, office costs, 
engineering, and design. Total capital investment is the sum of fixed capital investment, start-up cost, and working capital.

Table 7. Economic Evaluation Summary

\begin{tabular}{|c|c|c|c|c|c|}
\hline & CASE 1 & CASE 2 & CASE 3 & CASE 4 & CASE 5 \\
\hline Feedstock Type & ONP & ONP & Mixed & Mixed & Mixed \\
\hline Plant Size Dry tpd & 2,000 & 2,000 & 2,000 & 2,000 & 1,000 \\
\hline Performance Estimate & Now & Future & Now & Future & Future \\
\hline SSF Cellulase Loading IU/g & 10 & 3 & 10 & 3 & 3 \\
\hline SSF Conversion $\%$ & 75 & 90 & 75 & 90 & 90 \\
\hline SSF Time - Days & 7 & 3 & 7 & 3 & 3 \\
\hline SSF Seed - Y/N & Yes & No & Yes & No & No \\
\hline $\begin{array}{l}\text { Capital Cost } \$ \text { Million } \\
\text { (1990) }\end{array}$ & 126 & 94 & 119 & 87 & 52 \\
\hline $\begin{array}{l}\text { Ethanol Price } \$ / \mathrm{Gal} \\
\text { with Feed @ } \$ 25 / \mathrm{D} \text { Ton }\end{array}$ & $\begin{array}{c}1.02 \\
(0.77)\end{array}$ & 0.64 & $\begin{array}{c}1.06 \\
(0.79)\end{array}$ & 0.67 & 0.80 \\
\hline $\begin{array}{l}\text { Ethanol Price } \$ / G a l \\
\text { with Feed @ } \$ 10 / \mathrm{D} \text { Ton }\end{array}$ & $\begin{array}{c}0.80 \\
(0.59)\end{array}$ & 0.47 & $\begin{array}{c}0.84 \\
(0.62)\end{array}$ & 0.50 & 0.63 \\
\hline $\begin{array}{l}\text { Ethanol Product } \\
\text { Million Gal/yr }\end{array}$ & 45.9 & 58.5 & 46.8 & 59.4 & 29.7 \\
\hline
\end{tabular}

Notes:

(1) SSF cellulase loading is the amount of cellulase in international units (IU) per gram of cellulose in the feed.

(2) SSF conversion is defined as the percentage of cellulose available that is converted to ethanol.

(3) SSF seed fermentation: "No" means cell recycle is employed.

(4) Ethanol costs in parentheses are for a plant built based on current technology that takes advantage of process improvements from R\&D.

Operating costs include variable and fixed costs. Variable costs including those for feedstocks, chemicals, and disposal were calculated based on material balance requirements. The cost for disposal of the ash in a landfill was assumed to be the national average of $\$ 27 /$ ton for nonhazardous material. Fixed operating costs include labor, supervision, overhead, maintenance, insurance, and taxes. Excess production of electricity was assumed to be sold at $\$ 0.04 /$ kilowatt-hour $(\mathrm{kWh})$ with revenues treated as a by-product credit against production costs. It may be possible to take advantage of "avoided cost" electricity rates for cogeneration plants, in which case the selling price of excess electricity may be considerably higher than this assumption. This, of course, reduces the net ethanol selling price.

Finally, the annual cost of ethanol production is the sum of variable and fixed operating costs plus an annual capital charge of $20 \%$ of the total capital investment less any by-product credits. The cost of ethanol per gallon is the annual cost of ethanol production divided by the annual production rate. Table 7 summarizes the basic assumptions and results of the five cases. Figure 3 shows how ethanol cost varies as a function of feedstock cost for the five cases evaluated. 


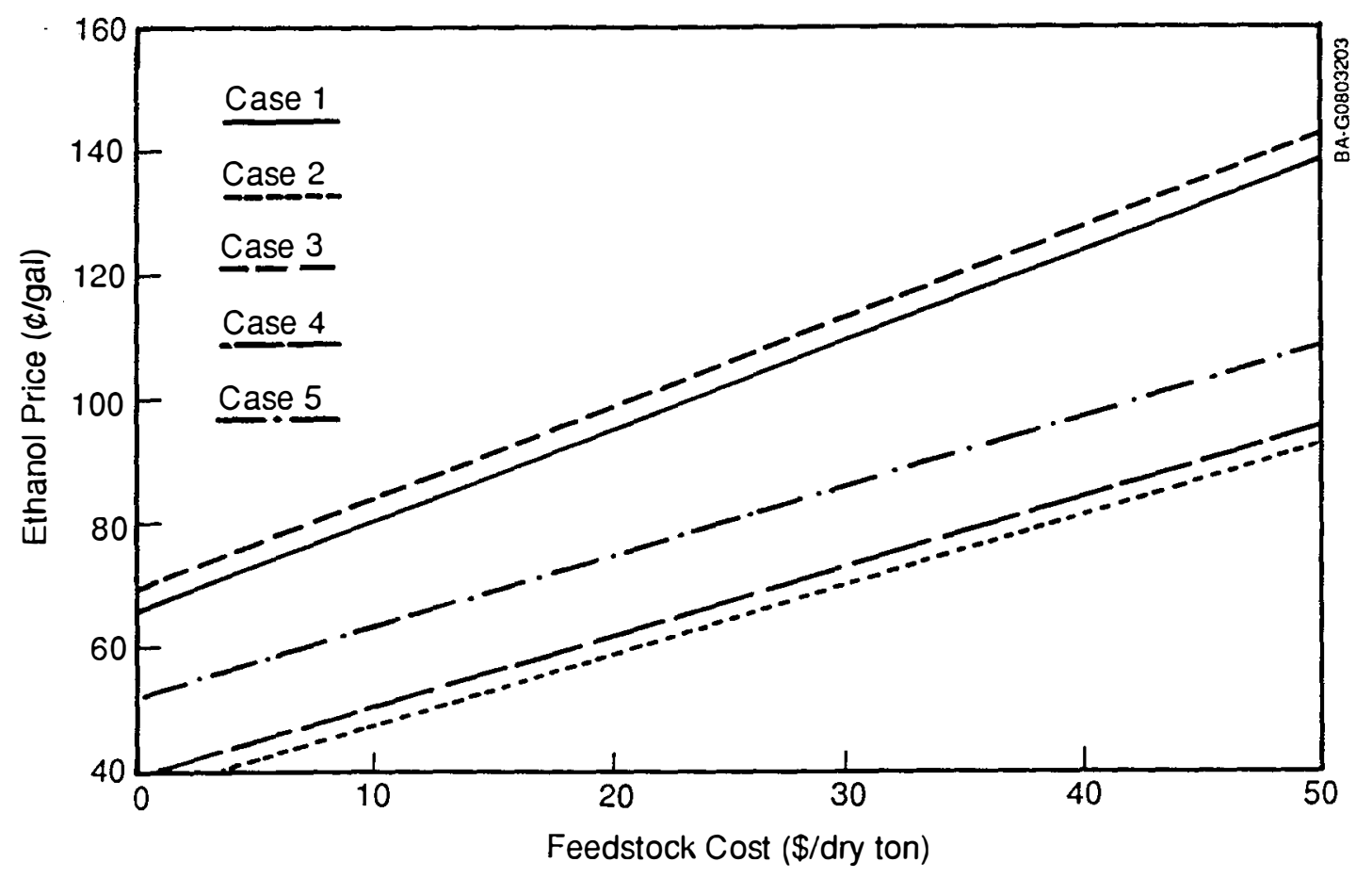

Figure 3. Ethanol price as a function of feedstock cost

\section{Results of the Economic Analysis}

The ethanol selling prices listed in Table 7 range from a low of $\$ 0.47 /$ gal up to $\$ 1.06 /$ gal. Because ONP contains more lignin than the mixed papers, more electricity is produced. This increases the capital cost and, more importantly, the by-product credits relative to mixed papers. ONP also contains less ash, which results in lower disposal costs. These factors overcome ONP's lower ethanol production capacity, which is a result of its lower glucose content. Although the ONP feedstock cases show slightly lower ethanol prices than mixed paper prices, they are essentially equivalent given the accuracy of the analysis. Therefore, the rest of the discussion will focus on the mixed paper cases.

As shown in Table 6, the mixed papers sample analyzed had almost $10 \%$ ash. Therefore, the landfill fee was raised from $\$ 27 /$ ton to $\$ 100 /$ ton for cases 3,4 , and 5 to determine its effect on the ethanol selling price. The effect in each case was to raise the ethanol selling price by about $\$ 0.10 / \mathrm{gal}$. This is a significant increase in the selling price, but does not change the general trend of the results as discussed below.

All the prices in Table 7 are well below recent fuel ethanol prices, which fluctuate around \$1.30-1.40/gal. Given the $\$ 0.60 /$ gal tax credit currently applied to fuel ethanol, the cases based on "current" technology produce ethanol at about $\$ 0.46 /$ gal using $\$ 25 /$ ton wastepaper and $\$ 0.24 /$ gal using $\$ 10 /$ ton feedstock. These prices are below those of any current transportation fuel. If the $\$ 0.44 /$ gal difference between the $\$ 1.06 / \mathrm{gal}$ for case 3 and the current approximate fuel ethanol selling price of $\$ 1.50 / \mathrm{gal}$ was spent on feedstock, the wastepaper facility could pay $\$ 56 /$ ton for the wastepaper. Without the tax credits, current technology would still be competitive as an oxygenated octane booster at wastepaper prices around $\$ 10 /$ ton. 
However, the tax credit will most likely be phased out in the future, and ethanol will have to stand on its own merits at that time. In light of this, the price goal of the U.S. Department of Energy's (DOE) ethanol program is $\$ 0.67 /$ gal (1990 dollars). This price will allow ethanol to compete with gasoline as a fuel rather than as an oxygenated octane booster. With this in mind, only the future ethanol technology cases are economical. For a 2,000-tpd plant, the feedstock cost can go as high as $\$ 25 /$ ton, and for a 1,000-tpd plant, the feedstock cost must be near $\$ 10 /$ ton to meet the program goal. Plants that are built based on current technology but that take advantage of process improvements resulting from the DOE's research and development program can ultimately produce ethanol at $\$ 0.62 /$ gal from feedstock priced at $\$ 10 /$ ton and $\$ 0.79 / \mathrm{gal}$ at $\$ 25 /$ ton. This indicates that a plant can still meet the ethanol program cost goal of $\$ 0.67 /$ gal with a feedstock cost of about $\$ 12.50 /$ ton once process improvements incorporated in the "future" technology cases are available and incorporated. It is interesting to note that a plant, if built soon enough, could operate during the time of tax credits and could, therefore, make a substantial profit during that time. Of course, this is only possible if the ethanol conversion technology described by the current technology case is technically proven for wastepaper feedstocks. A major technical uncertainty lies in the feedstock preparation area where only a hydropulper is assumed needed to prepare the wastepaper for SSF. Defining a better pretreatment will require research because most paper products are made from softwoods for which effective pretreatment options have not been developed for ethanol production.

\section{Conclusions}

Although there is currently a well-known glut of certain grades of wastepaper such as ONP, the demand for wastepaper from the domestic and foreign pulp and paper industries is predicted to increase dramatically. This industry represents the largest competitive demand for wastepaper and can outbid ethanol production for the wastepaper it wants. Because it wants mostly well-sorted and uncontaminated wastepaper, wastepaper in the mixed paper category collected before and after its introduction into MSW represents the largest potential source of wastepaper. Even if the aggressive wastepaper utilization rates predicted for the domestic and foreign paper and paperboard industries are achieved, there exists the possibility of producing 1-2 billion gallons of ethanol from wastepaper collected prior to MSW-mostly from mixed papers and from smaller contributions from OCC and ONP, mostly as cofeedstocks with mixed papers and perhaps from wood and herbaceous crops.

Utilization of MSW for ethanol production also holds considerable potential because of its considerable volume and the fact that the competition for its use comes from production of a low-value fuel rather than a relatively high-value paper product. Commercial technology currently exists to recover the materials (mostly wastepaper) appropriate for ethanol production.

A technoeconomic analysis was performed of a hypothetical wastepaper-to-ethanol process based on current laboratory scale data. From this analysis it was found that a 2,000-tpd wastepaper-to-ethanol plant could produce ethanol at prices competitive in today's ethanol market, which allows tax credits for ethanol blended with gasoline. The competitiveness of ethanol in this case could be maintained for wastepaper priced as high as $\$ 56 /$ ton. Without the tax credits, current technology could be competitive in the current oxygenated octane enlancer market using wastepaper priced at about $\$ 10 /$ ton. However, current technology as used in this paper applies to the wood-to-ethanol process technology and must be used with caution when applied to wastepaper as a feedstock. The main assumption that needs to be tested is in the definition of a suitable pretreatment prior to saccharification and fermentation. Because of a lack of information on suitable alternative options, the current technology design includes only a hydropulper to pretreat the wastepaper before SSF. 
The ethanol program goal of $\$ 0.67 /$ ton without tax credits could only be achieved using anticipated "future" technology at wastepaper prices of up to $\$ 25 /$ ton. If the plant size is reduced to 1,000 tpd, the future-technology-based plant requires wastepaper priced around $\$ 10 /$ ton. If a plant is built based on current technology (i.e., before the future technology performance improvements are developed) but adopts the process improvements as they are developed, it can still produce ethanol at the program goal if the feedstock cost at that time is around $\$ 12.50 /$ ton.

\section{Recommendations}

Additional information needs to be obtained about the technical and resource availability aspects of the conversion of wastepaper to ethanol. More laboratory data must be generated and scaled up to test the technical assumptions of the wastepaper-to-ethanol process model. Specific locations that can support a wastepaper-to-ethanol facility need to be found. The main criterion for the site is that it must have a sufficient quantity of economically collectible wastepaper that is not yet dedicated to alternative uses.

An internal study at NREL (Tyson 1990) investigated the availability of wastepaper in the western states and found eight sites where there was predicted to be more than 1,000 tpd available within a 70-mile radius. The study used a national average amount of wastepaper discarded and not recovered per person, and used county population estimates to calculate total wastepaper generation per county. It then assumed that $80 \%$ of that would be deliverable to an ethanol production facility. This study can provide the basis for a more in-depth market analysis that would take into account geographic differences in wastepaper supply and demand from alternative uses. This could pinpoint specific potential sites for a wastepaper-toethanol pilot plant, needed to develop the technology beyond the laboratory.

\section{References}

Cunningham, H. W. July 1990. Non-heatset Web Printing. Draft of Document AP 40, Washington, D.C.: American Newspaper Publishers Association.

Franklin Associates, Ltd. March 1988. Characterization of Municipal Solid Waste in the United States, 1960-2000 (Update 1988). PB88-232780. Washington, DC: Environmental Protection Agency.

Franklin, W. E. February 1990. Paper Recycling: The View to 1995; Summary Report Prepared for the American Paper Institute. Prairie Village, KS: Franklin Associates, Ltd.

The Future of Newspaper Recycling. May 3, 1990. Washington, DC: National Solid Wastes Management Association.

Iannazzi, F. D., and W. Strauss. March 1990. "Municipal Solid Waste and the Paper Industry: The Next Five Years." Pulp and Paper, Vol. 64, 4 pp.

Metropolitan Washington Council of Governments, Department of Environmental Programs. November 1989. Directory of Wastepaper Markets for the Metropolitan Washington Area. Washington, DC: Metropolitan Washington Council of Governments.

Miles, W. E. et al., eds. 1989. Pulp and Paper 1989 Fact Book. San Francisco, CA: Miller Freeman Publications Inc. 
Miles, W. E. et al., eds. 1988. Pulp and Paper 1988 Fact Book. San Francisco, Calif.: Miller Freeman Publications Inc.

NSWMA Annual Tip Fee Survey. 1988. Washington, DC: National Solid Wastes Management Association.

Printing Ink Handbook. 1988. Harrison, NY: National Association of Printing Ink Manufacturers, Inc.

Pulp \& Paper Week. 1990. (Vol. 12, Nos. 37, 41). San Francisco, Calif.: Miller Freeman Publications Inc.

Schell, D., C. Riley, P. Bergeron, and P. Walter. June 1991. Internal NREL document.

Tyson, S. Personal communication. November 1990. 


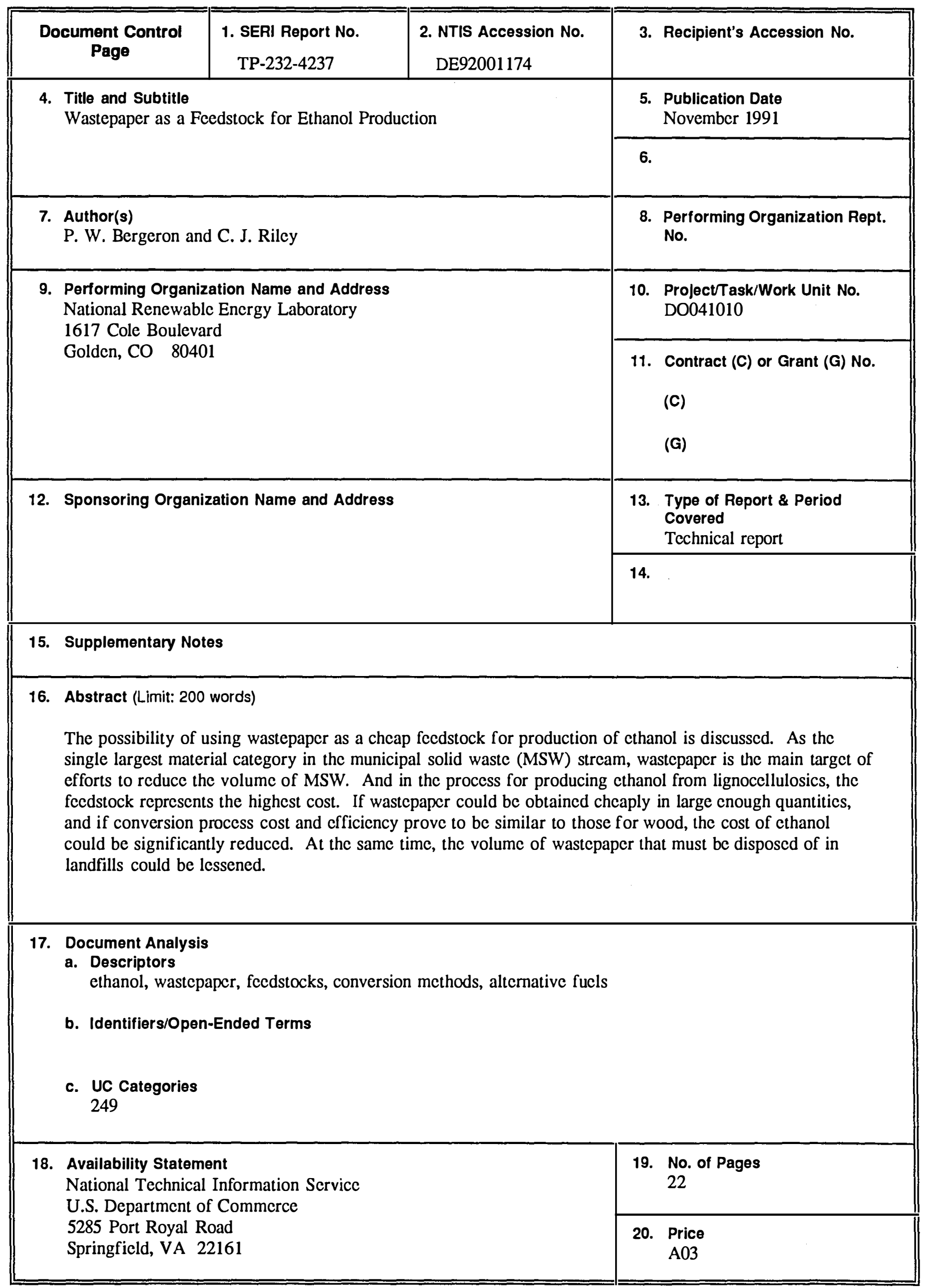

